\title{
PROTEOMICS
}

\section{Comparative proteome analysis of metabolic proteins from seeds of durum wheat (Cv. Svevo) subjected to heat stress}

\begin{tabular}{|r|l|}
\hline Journal: & PROTEOMICS \\
\hline Manuscript ID: & Draft \\
\hline Diley - Manuscript type: & Research Article \\
\hline Author: & \\
\hline Complete List of Authors: & $\begin{array}{l}\text { Laino, Paolo; University of Tuscia, Agrobiology and Agrochemistry } \\
\text { Shelton, Dale; DTU, Systems Biology } \\
\text { Finnie, Christine; DTU, Systems Biology } \\
\text { De Leonardis, Anna Maria; CRA, Cereal Research Centre } \\
\text { Mastrangelo, Anna Maria; CRA, Cereal Research Centre } \\
\text { Svensson, Birte; DTU, Systems Biology } \\
\text { Lafiandra, Domenico; University of Tuscia, Agrobiology and } \\
\text { Agrochemistry } \\
\text { Masci, Stefania; University of Tuscia, Agrobiology and } \\
\text { Agrochemistry }\end{array}$ \\
\hline \hline Key Words: & $\begin{array}{l}\text { Durum wheat, Heat stress, Wheat kernel proteome, Wheat kernel } \\
\text { metabolic proteins }\end{array}$ \\
\hline
\end{tabular}

\section{s ScholarONE" \\ Manuscript Central}


Laino Paolo $^{1,2}$, Shelton Dale ${ }^{2 \Phi}$, Finnie Christine ${ }^{2,}$, De Leonardis Anna Maria ${ }^{3}$, Mastrangelo Anna Maria $^{3}$, Svensson Birte ${ }^{2}$, Lafiandra Domenico $^{1}$, Masci Stefania $^{1 *}$

${ }^{1}$ Department of Agrobiology and Agrochemistry, University of Tuscia, Via S. Camillo De Lellis snc, 01100 Viterbo, Italy

${ }^{2}$ Enzyme and Protein Chemistry, Department of Systems Biology, Technical University of Denmark, Søltofts Plads Building 224, DK-2800 Kgs. Lyngby, Denmark

${ }^{3}$ C.R.A. - Cereal Research Centre, S.S. 16 km 675, 71122 Foggia, Italy

${ }^{\Phi}$ Present address: Institute for Plant Biology, Faculty of Life Science, University of Copenhagen, Thorvaldsensvej 40, 1841 Frederiksberg C, Denmark

\begin{abstract}
*Corresponding author: Prof. Stefania Masci, DABAC, University of Tuscia, Via S. C. de Lellis snc, 01100 Viterbo (Italy), e-mail: masci@unitus.it, fax: 00390761 357238, tel. 00390761357255
\end{abstract}

\footnotetext{
Abbreviations: FDR, false discovery rate; GAPDH, glyceraldehyde-3-phosphate dehydrogenase; LEA, Late Embryogenesis Abundant; NDPK, Nucleoside diphosphate kinase
}

Keywords: Durum Wheat; Heat Stress; Wheat Kernel Proteome; Wheat Kernel Metabolic Proteins 


\begin{abstract}
In Central and Southern Italy, where durum wheat represents one of the most widely cultivated crops, grain filling occurs during Spring, a period characterised by sudden increases in temperature. Wheat grain proteins are classified into albumins, globulins, and prolamins. The non-prolamin fractions include proteins with metabolic activity or structural function.

In order to investigate the consequences of heat stress on the accumulation of non-prolamin proteins in mature durum wheat kernels, the Italian cultivar Svevo was subjected to two thermal regimes (heat stress $v s$. control) during grain filling. The 2D patterns of non-prolamin proteins were monitored to identify polypeptides affected by heat stress. This study shows that heat stress alters significantly the durum wheat seed proteome, although the fold changes range only between 1.2 and 2.2. This analysis revealed 132 differentially expressed polypeptides, 47 of which were identified by MALDI TOF and MALDI-TOF-TOF MS and included heat shock proteins, proteins involved in the glycolysis and carbohydrate metabolism, as well as stress related proteins. Many of the heat induced polypeptides are considered to be allergenic for sensitive individuals.

The differences observed with previously reported data regarding bread wheat may be explained by the absence of the $\mathrm{D}$ genome in durum wheat.
\end{abstract}




\section{INTRODUCTION}

Wheat is a widely used cereal for human consumption. The two most important cultivated wheat species are Triticum aestivum L. (bread wheat) and T. durum Desf. (durum wheat). T. aestivum is a hexaploid species possessing the genomes AABBDD, whereas T. durum is tetraploid with genome composition AABB. This last species is extremely important, in the Mediterranean areas, where represents the most widespread crop, finding large utilization in the production of a wide range of end products, such as pasta, leavened and unleavened breads, cous cous etc. Genes present on D chromosomes, such as those determining flour texture [1] or those encoding specific high molecular weight glutenin subunits [2], missing in durum wheat, confer the typical bread-making properties to bread wheat flour. In addition, the absence of the D genome in durum wheat may affect also the response to biotic and abiotic stresses, because it has been shown that several stress-related genes are located on the D genome $[3,4]$.

Abiotic stresses, such as drought, salinity, extreme temperatures, chemical toxicity, and oxidative stress are serious threats to agriculture because they affect quality properties, including yield, and the characteristics of the final product. These effects stem from altered synthesis and functionality of specific protein [5]. Proteome analysis is an effective tool for investigation of changes in protein accumulation in wheat kernel in response to heat stress [6].

The seed protein content is the most important factor determining wheat quality. Wheat kernel proteins are divided according to their solubility properties into prolamins (gliadins and glutenins, collectively known as gluten proteins), soluble in diluted acid or alkali or alcohol-water mixtures, and albumins and globulins, which are water and salt soluble, respectively [7]. Gluten proteins represent about $80 \%$ of wheat seed proteins, and are the most important determinant of the dough properties. 
High temperature during the grain filling has been reported to alter the yield and the dough quality of bread wheat $[8,9]$. Heat stress, in fact, modifies the ratio between the different gluten proteins in the seed by affecting mainly the composition of the polymeric fraction (soluble/insoluble polypeptides) [10]. High temperatures thus favor synthesis of gliadins, whereas glutenin synthesis decreases. An explanation of the gliadin increase after heat stress might be related to the presence of heat stress elements (HSE) in the upstream regions of some gliadin genes [10]. Because glutenins, however, are the most important polypeptides in determining quality properties, their decrease, coupled to the relative increase of gliadins, might explain the negative performance of bread wheat exposed to high temperatures.

Water-soluble albumins and salt-soluble globulins constitute about $20 \%$ of total flour protein $[11,12]$. The non-prolamin proteins have mainly metabolic activity or structural functions [13]. Certain wheat globulins, however, are reported to be storage proteins [14,15]. In contrast to gliadins and glutenins, albumins and globulins have been less thoroughly characterized, most probably due to their minor role in wheat quality compared to gluten proteins, although the ratio of albumin to globulin has been reported to correlate with bread-making quality [11]. A relationship between the water-soluble $\alpha$-amylase/trypsin inhibitors and pasta quality has also been suggested [16,17]. The soluble proteins from wheat seeds are now receiving increasing attention because several polypeptides from this fraction have been identified as human allergens [18].

Effects of heat stress on metabolic proteins in wheat kernel were previously studied in bread wheat kernels. One of the consequences was a reduction in starch accumulation and activity of soluble starch synthase [19-21]. More recently, proteome analysis of bread wheat showed the involvement of enzymes in starch biosynthesis, e.g. glucose-1-phosphate adenyltransferase and the granule bound starch synthase in heat stress response. In addition, up-regulation of a large number of cytoplasmic heat shock proteins (HSP) was confirmed [6]. 


\section{Plant material and heat treatment}

Durum wheat ( $c v$ Svevo) was grown in a climate chamber in a medium composed of soil, sand, peat $(6: 3: 1)$ at $10^{\circ} \mathrm{C}(9 \mathrm{~h}$ day $) / 7^{\circ} \mathrm{C}(15 \mathrm{~h}$ night $)$ with $60 \%$ relative humidity and photon flux of $500 \mu \mathrm{mol}$ $\mathrm{m}^{-2} \mathrm{~s}^{-1}$ until appearance of the third leaf. At this point, conditions were gradually (according to the development stage $)$ switched to $20^{\circ} \mathrm{C}(13 \mathrm{~h}$ day $) / 17^{\circ} \mathrm{C}(11 \mathrm{~h}$ night $)$ with $55 \%$ relative humidity and photon flux of $500 \mu \mathrm{mol} \mathrm{m} \mathrm{m}^{-1}$. These conditions were maintained until five days after anthesis. Then, while control plants were maintained in the same conditions, stressed plants were subject to heat-shock treatment, carried out at $37 / 17^{\circ} \mathrm{C}(13 \mathrm{~h}$ day/11 h night $)$ with $55 \%$ relative humidity for 5 days. Following the heat shock, the temperature was decreased to $28^{\circ} \mathrm{C}$ for $4 \mathrm{~h}$, and then the growing cycle was set up at $20^{\circ} \mathrm{C}(13 \mathrm{~h}$ day $) / 17^{\circ} \mathrm{C}(11 \mathrm{~h}$ night $)$ with $55 \%$ relative humidity and 500 $\mu \mathrm{mol} \mathrm{m} \mathrm{s}^{-1}$ photon flux. Starting from the milk maturity stage, both control and stressed plants were brought to complete maturity at $25^{\circ} \mathrm{C}(16 \mathrm{~h}$ day $) / 20^{\circ} \mathrm{C}(8 \mathrm{~h}$ night $)$ with $45 \%$ relative humidity. In both control and stress treatments, seeds were collected from four biological replicas. 


\section{Protein content analysis and selective extraction}

The seed protein content was determined by Kjeldahl nitrogen analysis (Nx5.7). Metabolic seed proteins were extracted according to [23], but amounts were scaled up in order to perform larger 2D gels. Briefly flour $(150 \mathrm{mg})$ was suspended in $600 \mu \mathrm{l}$ of cold $\mathrm{KCl}$ buffer $(50 \mathrm{mM}$ Tris-HCl, 100 $\mathrm{mM} \mathrm{KCl,} 5 \mathrm{mM}$ EDTA, pH 7.8). The suspension was incubated on ice for 5 min with intermittent mixing and centrifuged $\left(14,500 \mathrm{~g}, 15 \mathrm{~min}, 4^{\circ} \mathrm{C}\right)$. The $\mathrm{KCl}$-soluble fraction was collected and 5 volumes $(\mathrm{v} / \mathrm{v})$ of cold $0.1 \mathrm{M}$ ammonium acetate in methanol were added at room temperature. Following incubation overnight at $-20^{\circ} \mathrm{C}$, the methanol-insoluble fraction was pelleted by centrifugation as above. The pellet (containing metabolic proteins) was rinsed with cold acetone, dried down and stored at $-20^{\circ} \mathrm{C}$ until further use.

\section{2-DE}

Metabolic proteins were dissolved in $800 \mu \mathrm{l}$ of strip rehydration buffer containing $7 \mathrm{M}$ Urea, $2 \mathrm{M}$ thiourea, 2\% (w/v) CHAPS, 2\% (v/v) Triton X100, 1.2\% (v/v) Destreak reagent (GE Healthcare), and $0.5 \%(\mathrm{v} / \mathrm{v})$ IPG buffer $\mathrm{pH} 3-10$. IEF linear IPG strips (18 cm, GE Healthcare) $\mathrm{pH} 3-10$ were used as first dimension. Strips were rehydrated overnight at $20^{\circ} \mathrm{C}$ with $200 \mu \mathrm{L}$ of dissolved proteins (about $300 \mu \mathrm{g}$ protein) and $150 \mu \mathrm{l}$ of rehydration buffer was added. The same extract volume (200 $\mu \mathrm{L})$ was loaded. Focusing was performed at $20^{\circ} \mathrm{C}$ for $80 \mathrm{kVh}(200 \mathrm{~V} 4 \mathrm{~h}, 500 \mathrm{~V} 2.5 \mathrm{~h}, 1000 \mathrm{~V} 3 \mathrm{~h}$, $5000 \mathrm{~V} 2$ h, $8000 \mathrm{~V} 9 \mathrm{~h}$ ). The gel strips were subsequently equilibrated for $25 \mathrm{~min}$ in $0.1 \mathrm{M}$ Tris$\mathrm{HCl} \mathrm{pH} 8.8$ containing $6 \mathrm{M}$ Urea, 30\% (w/v) glycerol, 2\% (w/v) SDS, 1\% (w/v) DTT and bromophenol blue as tracking dye. For the second dimension, the strips were transferred onto $18 \times$ $20 \mathrm{~cm}$ polyacrylamide gels $(15 \% \mathrm{~T}, 1.28 \% \mathrm{C})$ (Protean II X-Cell, BioRad) and run at $40 \mathrm{~mA}$ per gel for $3-4 \mathrm{~h}$ at $11^{\circ} \mathrm{C}$ until the dye front left the gel. 


\begin{abstract}
After electrophoresis, proteins were visualized by CBB staining according to [24]. All gels were stained for $16 \mathrm{~h}$ and destained for $1 \mathrm{~h}$ with distilled water before image acquisition. Three technical replicas were performed for each of the four biological replicas from each treatment, giving a total of 24 gels. Destained gels were scanned with Image Master LabScan (GE Healthcare) and analyzed using the software SameSpots Progenesis (vers. 1.0.2602.33289, Nonlinear Dynamics, UK). This software includes statistical analyses such as ANOVA $(\mathrm{p} \leq 0.05)$, determination of False Discovery Rate (FDR, $\mathrm{q} \leq$ 0.05), and Principle Component Analysis (PCA) calculated according to [25].
\end{abstract}

\title{
Protein identification by MALDI TOF-TOF
}

Protein identification was done by picking gel spots from two independent gels to minimize technical variability. CBB-stained spots were excised from the gel, cut to pieces and washed twice with $40 \%$ ethanol until colorless. The destained gel pieces were dehydrated with ACN, treated with $10 \mathrm{mM}$ DTT in $50 \mathrm{mM} \mathrm{NH}_{4} \mathrm{HCO}_{3}$ for $1 \mathrm{~h}$ at $56^{\circ} \mathrm{C}$ and finally alkylated with $55 \mathrm{mM}$ iodoacetamide in $50 \mathrm{mM} \mathrm{NH}_{4} \mathrm{HCO}_{3}$ for $30 \mathrm{~min}$ in the dark. Gel pieces were dehydrated with $\mathrm{ACN}$, rehydrated with 1 pmol trypsin (Sigma) solution in $50 \mathrm{mM} \mathrm{NH}_{4} \mathrm{HCO}_{3}$ and incubated at $37^{\circ} \mathrm{C}$ overnight for digestion. The peptides were extracted twice from gel slices with $5 \%$ formic acid in $50 \%$ ACN. The peptide solution was then desalted, concentrated and applied to an Anchorchip target ${ }^{\mathrm{TM}}$ (Bruker Daltonic) using $\alpha$-cyano-4-hydroxycinnamic acid as matrix, according to the manufacturer's instructions and [26]. Mass spectrometric analysis was performed on a MALDI TOF-TOF Ultraflex II in positive ion reflector mode and spectra were processed and analysed using the software FlexAnalysis and BioTools (Bruker Daltonics). Database searching was carried out using an inhouse MASCOT server (Matrix Science, London, UK) to search NCBInr

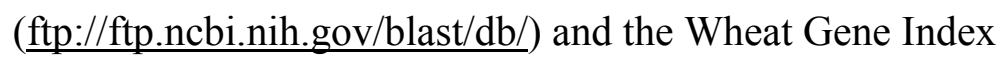
(http://compbio.dfci.harvard.edu/tgi/tgipage.html) release 10. 
Proteins were identified by PMF. Matrix contaminants and predominant keratin peaks were removed from peak lists using PeakErazor (http://www.protein.sdu.dk/gpmaw/Help/PeakErazor/peakerazor.html). In order to identify a protein unambiguously the following criteria were used: MASCOT score with $\mathrm{p} \leq 0.05$; protein sequence coverage $>15 \%$; at least five independent peptides matching with a mass tolerance of $50 \mathrm{ppm}$ and maximum one trypsin miscleavage site. The Oxidation (M) and the Gln->pyro-Glu were selected as variable fragment modifications. Where the PMF-based identification was uncertain, fragment ion spectra were obtained for at least three peaks with a signal:noise ratio $>5$ and $\mathrm{m} / \mathrm{z}>1400$. Each fragment ion spectrum was checked against the same database as used for PMF and the identification was confirmed if correspondence was found.

\section{RESULTS AND DISCUSSION}

Heat stress can be an important factor affecting yield and quality of durum wheat Although quality is mostly determined by gluten proteins, that are the major protein components of wheat seeds, also the soluble metabolic protein fraction (albumins and globulins) plays a role, especially in terms of nutritional/antinutritional properties. Most of these polypeptides, in fact, show allergenic properties in sensitive individuals [18]. Albumins and globulins are distributed mainly in the outer layers of wheat kernels, and thus are important components in whole-wheat flours and semolina, towards which there is an increasing consumer interest, because they have a higher amount of fibers, proteins and functional components [27].

In the present paper the durum wheat cultivar Svevo, widely grown in Italy and moderately resistant to cold stress, was subjected to two thermal regimes, i.e. heat stress and control conditions during 
grain filling. The effect on the metabolic protein fraction was analysed by comparison of the corresponding proteomes.

Firstly, protein contents were compared between stressed and control samples, which revealed that heat stressed samples accumulated significatively higher amounts of protein. The protein content being $19.30 \%( \pm 1.43)$ in stressed and $13.85 \%( \pm 1.87)$ in control samples $(p=0.004)$. A correlation between heat stress and increase in protein content was previously reported in bread wheat [28]. In our case, the increase in protein content was due mostly to gluten proteins, that were about $50 \%$ more abundant in heat stressed samples with respect to control samples, whereas the metabolic fraction increased by about $20 \%$ (data not shown).

The highly reproducible 2-D gels showed about 1000 spots in the $\mathrm{pI}$ range 3-10 and comparison revealed differential expression of proteins $(1.2<$ fold change $<2.2)$ in 132 spots (Fig. 1), 65\% were up-regulated in heat-treated samples (Fig. 2). Because only those spots satisfying ANOVA ( $<<0.05)$ and FDR $(\mathrm{q}<0.05)$ values were chosen, and the Principal Component Analysis (PCA) performed on the differentially expressed spots [25] indicated two separate groups corresponding to the two thermal regimes (Fig. 3), we are confident that the observed differences are significant.

\section{Protein identification}

MALDI TOF analysis identified 47 proteins from the picked varying spots (Table 1; Fig. 4). Among the identified proteins, $85 \%$ were up-regulated and $15 \%$ down-regulated. Proteins identified by mass spectrometry were classified based on to their main activity although most are involved in different pathways or signaling.

Noteworthy is the observation that the fold changes observed, are in a narrow range $(1.2>$ fold change $>2.2$ ). This is in agreement with previous findings relative to the bread wheat cultivar Butte $86[29]$. 
As expected, heat stress increased expression of many proteins related to desiccation and oxidation stress, e.g. Late Embryogenesis Abundant (LEA)-proteins, the heat shock proteins HSP70 and HSP26 [5, 30-32]. These proteins, through binding or interaction with other proteins, prevent damage of proteins and cell membranes (reviewed in [33]). Also glyoxalase I, one of the enzymes of the glyoxalase pathway related to the detoxification pathway of methylglyoxal in plants [34] was up-regulated.

\section{Carbohydrate metabolism or energy related proteins}

Nucleoside diphosphate kinase (NDPK), which is required for the synthesis of nucleotide triphosphate precursors of DNA and RNA, was up-regulated along with some housekeeping enzymes involved in glycolysis and the pentose phosphate pathway (glyceraldehyde 3-phosphate dehydrogenase, phosphoglycerate kinase, and glucose and ribitol dehydrogenase), in agreement also with that reported in [29], in which the effect of high temperature on soluble proteins of developing bread wheat grains has been studied. Altered expression pattern of NDPK was previously found in response to abiotic (including heat stress) and biotic stresses in rice and other plant species [35-36], suggesting that NDPK plays a regulatory role in addition to its primary metabolic functions.

Five spots $(427,444,460,503,514)$ which were up-regulated by heat stress contained glyceraldeyde 3-phosphate dehydrogenase (GADPH), which is involved in glycolysis and has been identified as one of the allergens implicated in bakers' asthma [18]. Bustos and Iglesias [37] reported that wheat endosperm and shoot GAPDH undergoes posttranslational phosphorylation enabling interaction with 14-3-3 family proteins, thus exerting a regulation aimed at maintaining the levels of energy and reductants in the cytoplasm. Recently, it was established using a proteomics approach that GAPDH activity in Arabidopsis was inhibited by $\mathrm{H}_{2} \mathrm{O}_{2}$, suggesting that GAPDH is a direct target of $\mathrm{H}_{2} \mathrm{O}_{2}$ and might have a role in mediating ROS signaling in plants [38]. 
1

2

3

4

5

6

7

8

9

Three up-regulated spots $(436,470,502)$ belonged to the glucose and ribitol dehydrogenase protein family.

Among the polypeptides down-regulated after heat shock, ATP synthase $\beta$ subunit (spot 110) was identified, in agreement with observations in bread wheat [6]. The decrease in amount of ATP synthase may affect energy-dependent processes involved in heat stress resistance. It has been reported that energy consuming processes are the primary cellular targets for a decreasing of ATP demand in response to stresses, such as anoxia [39], and it is known that heat shock and anoxia are abiotic stresses eliciting similar cellular responses [40].

Also phosphoglycerate kinase (spot 109), glycoside hydrolase family 85 (spot 173), and fructose 6 phosphate-phosphotransferase (spot 299), all involved in glycolysis, were down-regulated. The glycoside hydrolase family is present in essentially all living organisms and has been implicated in a diversity of roles, such as biomass conversion in microorganisms and activation of defense compounds, phytohormones, lignin precursors, aromatic volatiles, and metabolic intermediates [41]. Phoshoglycerate kinase was previously found to be over-expressed in the nuclear proteome of Arabidopsis in the cold stress response [42].

\section{Stress related}

Two members of the heat shock protein family, HSP70 (spots 70, 426) and HSP26 (spot 497) were up-regulated after the heat stress. HSP70s have been linked to the development of acquired thermotolerance in heat stress, although they seem also to correlate with tolerance to low temperature stress [43]. HSP26 belongs to the family of small heat shock proteins (sHSP) exhibiting chaperone activity and thought to protect proteins from irreversible aggregation [44].

A polypeptide of the 14-3-3 protein family was slightly down-regulated by heat stress (spot 341 ). Also Hurkman et al [29] observed down-regulation of members of this protein family after heat stress in bread wheat. Transcripts encoding proteins belonging to the 14-3-3 family accumulate in 
barley after biotic stresses $[45,46]$ and in wheat a region of chromosome $4 \mathrm{AL}$ containing genes coding for 14-3-3 is associated with a resistance QTL against specific fungal diseases [47]. The upregulated polypeptides after heat treatment moreover included flavonoid $O$-methyltransferase (spot 445), a 14-3-3-binding protein involved in production of antimicrobial secondary metabolites ,thus showing a potential role in response to a pathogen attack in barley [48]. Furthermore these compounds have antioxidants properties and could thus be involved in oxidative stress.

Serpins (serine protease inhibitors) were identified in multiple spots $(89,94,395,456)$ as upregulated in response to high temperature. The same observation was made by Hurkman et al [29]. Serpins, found in the soluble fraction of wheat seeds, undergo differential regulation in response to environmental stress [49]. The serpins are widespread in the plant kingdom and represent up to $4 \%$ of the total protein in the mature endosperm of cereal grains [50,51]. While the precise physiological role of serpins remains unclear, their activity suggests that they are involved in inhibition of endogenous proteases, or proteases from grain pests. Because of their high concentration in the endosperm, serpins have potential to influence grain quality traits [52-54]. Other proteins with a defense role have a modified expression profile in response to heat shock. Such proteins are typically identified in multiple forms on 2-D gels [55] and include: tritins (spots 140, 222), $\alpha$-amylase inhibitors (spot 362), and some 14-3-3 related or binding proteins. Most of these proteins besides having a metabolic role, are also considered as storage proteins. Furthermore, some are also considered wheat grain allergens along with the serpins [56].

Another enzyme found in response to the heat treatment is glyoxalase I (spot 508). The glyoxalase system is a set of enzymes that carry out detoxification of methylglyoxal and other reactive aldehydes that are produced during normal metabolism. In plants it has been demonstrated that different kinds of stress, such as salt and metal stress, elicits enhance the expression of glyoxalase I [57-59]. 
LEA proteins (spots 483 and 484) were up-regulated and are involved in stress responses. They are typically correlated with cellular dehydration in response to cold stress. Other LEA functions include roles as antioxidants and membrane and protein stabilisers during water stress [60]. Finally, 1-Cys peroxiredoxin (spot 14), also observed to be up-regulated, has antioxidant and chaperone activity [61].

\section{Storage proteins}

Up-regulated proteins with a storage role here identified in the heat response mainly belong to the globulin-like protein family (spots 110, $232350,509,511$ ) or protein homologous to embryo globulin (spots 58, 239, 468, 505). Spot 239 (Homologue to Embryo Globulin) was found to be down-regulated by heat stress. A role for these proteins in thermotolerance is not known. They may be directly related to heat stress response by an unknown mechanism or, indirectly, be a target for other proteins involved in the heat shock response. This is in agreement with [29].

\section{CONCLUDING REMARKS}

The results here reported offer a picture of the consequences of heat stress occurring during grain filling on the accumulation of the soluble proteins in the mature seeds of the widely grown Italian durum wheat $c v$ Svevo. The results provide a basis for understanding how this environmental change influences on protein synthesis and consequently the metabolic and quality traits of the durum wheat kernel. Moreover, since the durum wheat kernel is of primary interest because the semolina obtained by crushing mature seeds is the basis of many products of common use, among which pasta is the most important, it is critical to understand if the different types of stresses that wheat plants can potentially undergo, may alter protein composition, and, consequently, qualitative and nutritional properties of the derived products. 
In the present study 47 metabolic proteins were identified from the soluble seed fraction of durum wheat which were induced or repressed by heat shock. The fold changes observed were between 1.2 and 2.2, and this was also in agreement with [29].

In agreement with previous studies performed in bread wheat cultivars $[6,29,62]$ both HSP70 and LEA proteins were up-regulated in response to heat stress. Other proteins, such as ATP synthase $\beta$ subunit and nucleoside diphosphate kinase (NDPK) related to the energy metabolism also responded to heat treatment. This agrees also with the findings of Hurkman et al [29]. Interestingly, we did not find any difference in the level of expression of starch related enzymes, although this was a finding of Majoul et al [6] in bread wheat. This might be a result either of the different protein extraction procedures, or of a different protein turnover in the plant material, or the enzyme forms that are regulated in bread wheat may be coded by genes present on the $\mathrm{D}$ genome, that is absent in durum wheat.

GAPDH, a housekeeping enzymes involved in glycolysis, was found to be up-regulated. Others recently suggested a relationship between this enzyme and certain abiotic stresses [63]. Proteins reported to be influenced by abiotic stresses, e.g. oxidative and drought stresses, and also found as differentially regulated in the present work include 14-3-3 proteins, serpins, LEA proteins, 1-Cys peroxiredoxin, glyoxalase I, and proteins with a storage function (e.g. globulin-like proteins). It is noteworthy that some of the differentially regulated proteins are considered as allergens $(\alpha-$ amylase inhibitors, serpins, tritins, GAPDH) and were found to be up-regulated after heat stress, which obviously represents a disadvantage for sensitive individuals.

These results illustrate that there is a common network "response" to different types of abiotic stress, such as drought, oxidative, cold and heat stress. 


\section{ACKNOWLEDGMENTS}

This work was supported by the National project "Proteine e geni per la protezione delle piante dagli stress biotici e abiotici (PROTEO-STRESS), MIPAF. Paolo Laino was the recipient of a PhD fellowship in Plant Biotechnology funded by MIUR, "Fondo per il sostegno dei giovani e per favorire la mobilità degli studenti" in the framework "Valorizzazione dei prodotti tipici dell'agroalimentare e sicurezza alimentare attraverso nuovi sistemi di caratterizzazione e garanzia di qualità", and the recipient of a STMS award from the COST Action FA0603 Plant Proteomics. Birgit Andersen (Technical University of Denmark) is thanked for assistance with mass spectrometry. Dale Shelton was funded by a Large Multi-Disciplinary Research Grant from the Danish Research Council. The authors wish to acknowledge Dr. Federico Scossa (ENEA-Casaccia, Rome, Italy) for having performed protein content measurements. 


\section{Conflict of interest statement}

The authors declare that there is no financial/commercial conflict of interest 


\section{REFERENCES}

[1] Morris C.F., Puroindolines: the molecular genetic basis of wheat grain hardness. Plant Molec. Biol. 2002, 48, 633-647.

[2] Shewry, P.R., Halford, N.G., Tatham, A.S., Popineau, Y. et al., The high molecular weight subunits of wheat glutenin and their role in determining wheat processing properties. Adv. Food Nutr. Res. 2003, 45, 219-302.

[3] Boyko E.V., Gill K. S., Mickelson-Young L., Nasuda S. et al., A high-density genetic linkage map of Aegilops tauschii, the D-genome progenitor of bread wheat. Theor. Appl. Genet. 1999, $99,16-26$.

[4] Aprile, A., Mastrangelo, A.M., De Leonardis, A.M., Galiba, G. et al., Transcriptional profiling in response to terminal drought stress reveals differential responses along the wheat genome. BMC Genomics 2009, 10, art. no. 279.

[5] Timperio, A.M., Egidi, M.G., Zolla, L., Proteomics applied on plant abiotic stresses: Role of heat shock proteins (HSP). J. Proteomics 2008, 71, 4, 391-411.

[6] Majoul, T., Bancel, E., Triboï, E., Hamida, J.B., Branlard, G., Proteomic analysis of the effect of heat stress on hexaploid wheat grain: Characterization of heat-responsive proteins from nonprolamins fraction. Proteomics 2004, 4, 505-513.

[7] Osborne, T.B., The vegetable proteins. Longmans, Green \& Co., London, 1924.

[8] Stone, P.J., Nicolas, M.E., Wheat cultivars vary widely in their responses of grain yield and quality to short periods of post- anthesis heat stress. Aust. J. Plant Physiol.1994, 21, 887-900.

[9] Wardlaw, I.F., Blumenthal, C., Larroque, O., Wrigley, C.W., Contrasting effects of chronic heat stress and heat shock on kernel weight and flour quality in wheat. Funct. Plant Biol. 2002, 29, $25-34$.

[10] Blumenthal, C.S, Batey, I.L., Wrigley, C.W., Barlow, E.W.R., Involvement of a novel peptide in the heat shock response of Australian wheats. Aust. J. Plant Physiol. 1990, 17, 441-449. 
[11] Pence, J.W., Weinstein, N.E., Mecham, D., The albumin and globulin contents of wheat flour and their relationship to protein quality. Cereal Chem. 1954, 31, 303-311.

[12] Singh, J., Skerritt, J. H., Chromosomal control of albumins and globulins in wheat grain assessed using different fractionation procedures. J. Cereal. Sci. 2001, 33, 163-181.

[13] Goesaert, H., Gebruers, K., Courtin, C.M., Brijs, K., Delcour, J.A., Enzymes in breadmaking. In "Bakery products: science and technology”, Hui Y.H. Ed. 2006, pp. 337-364.

[14] Singh, N.K., Shepherd, K.W., The structure and genetic control of a new class of disulphidelinked proteins in wheat endosperm. Theor. Appl. Genet. 1985, 71, 79-92.

[15] Singh, N.K., Shepherd, K.W., Solubility behavior synthesis, degradation and subcellular location of a new class of disulfide linked proteins in wheat endosperm. Aust. J. Plant Physiol. $1987,14,245-252$.

[16] Kobrehel, K., Alary, R., The role of a low molecular weight glutenin fraction in the cooking quality of durum wheat pasta. J. Sci. Food Agric. 1989, 47, 487-500.

[17] Kobrehel, K., Alary, R., Isolation and partial characterization of two low molecular weight durum wheat (Triticum durum) glutenins. J. Sci. Food Agric. 1989, 48, 441-452.

[18] Tatham, A.S., Shewry, P.R., Allergens to wheat and related cereals. Clin. Exp. Allergy, 2008, $38,1712-1726$.

[19] Shy, Y.C., Seib, P.A., Bernardin, J.E., Effects of temperature during grain-filling on starches from six wheat cultivar. Cereal Chem. 1994, 71, 369-383.

[20] Hawker, J.S., Jenner, C.F., High temperature affects the activity of enzymes in the committed pathway of starch synthesis in developing wheat endosperm. Austr. J. Plant Physiol. 1993, 20, 197-209.

[21] Keeling, P.L., Bacon, P.J., Holt, D.C., Elevated temperature reduces starch deposition in wheat endosperm by reducing the activity of soluble starch syntase. Planta 1993, 191, 342-348. 
[22] Sancho, A.I., Gillabert, M., Tapp, H., Shewry, P.R., et al., Effect of environmental stress during grain filling on the soluble proteome of wheat (Triticum aestivum) dough liquor. Agr. Food Chem. 2008, 56, 5386-5393.

[23] Hurkman, W.J., Tanaka, C.K., Improved methods for separation of wheat endosperm proteins and analysis by two-dimensional gel electrophoresis. J. Cereal Sci. 2004, 40, 295-299.

[24] Neuhoff, V., Arold, N., Taube, D., Ehrhardt, W., Improved staining of proteins in polyacrylamide gels including isoelectric focusing gels with a clear background at nanogram sensitivity using Coomassie Brilliant Blue G-250 and R-250. Electrophoresis 1988, 9, 255-262.

[25] O’Gorman, M., Beauvallet, C., Lepercq, P. David, O., et al., An investigation into Crohn's disease using the Progenesis SameSpots analysis platform. $24^{\text {th }}$ Journée Françaises de Spectrométrie de Masse, PAU 2007.

[26] Zhang, X., Shi, L., Shu, S., Whang, Y., et al., An improved method of sample preparation on AnchorChip $^{\mathrm{TM}}$ targets for MALDI-MS and MS/MS and its application in the liver proteome projects. Proteomics 2007, 7, 2340-2349.

[27] Dewettinck, K., Van Bockstaele, F., Kühne, B., Van de Walle, D., et al.,. Nutritional value of bread: influence of processing, food interaction and consumer perception. J. Cereal Sci. 2008, $48,243-257$.

[28] Shewry, P.R., Napier, J.A., Tatham, A.S., Seed storage proteins: structures and biosynthesis. Plant Cell 1995, 7, 945-956.

[29] Hurkman, W.J., Vensel, W.H., Tanaka, C.K., Whitehand, L., Altenbach, S.B., Effect of high temperature on albumin and globulin accumulation in the endosperm proteome of the developing wheat grain. J. Cereal Sci. 2009, 49, 12-23.

[30] Treglia, A., Spano, G., Rampino, P., Giangrande, E., et al., Identification by in vitro translation and Northern blot analysis of heat shock mRNAs isolated from wheat seeds exposed to different temperatures during ripening. J. Cereal Sci. 1999, 30, 33-38. 
[31] Renaut, J., Hausman, J.-F., Wisniewski, M.E., Proteomics and low-temperature studies: bridging the gap between gene expression and metabolism. Physiol. Plant. 2006, 126, 97-109.

[32] Qureshi, M.I., Qadir, S., Zolla, L., Proteomics-based dissection of stress-responsive pathways in plants. J. Plant Physiol. 2007, 164, 1239-1260.

[33] Buitink, J., Hoekstra, F.A., Leprince, O., Biochemistry and biophysics of tolerance systems. Black, M and Pritchard, H.W. Eds., CAB International, Wallingford, UK., 2002.

[34] Hossain, M.A., Hossain, M.Z., Fujita, M., Stress-induced changes of methylglyoxal level and glyoxalase I activity in pumpkin seedlings and cDNA cloning of glyoxalase I gene. Aust. J. Crop Sci. 2009, 3, 53-64.

[35] Salekdeh, Gh.H., Siopongco, J., Wade, L.J., Ghareyazie, B., Bennett, J. Proteomic analysis of rice leaves during drought stress and recovery. Proteomics 2002, 9, 1131-1145.

[36] Hajheidari, M., Abdollahian-Noghabi, M., Askari, H., Heidari, M., et al., Proteome analysis of sugar beet leaves under drought stress. Proteomics 2005, 4, 950-960.

[37] Bustos, D.M., Iglesias, A.A., Phosphorylated Non-Phosphorylating Glyceraldehyde-3Phosphate Dehydrogenase from heterotrophic cells of wheat interacts with 14-3-3 proteins. Plant Physiol. 2003, 133, 2081-2088.

[38] Hancock, J.T., Henson, D., Nvirenda M., Desikan R., et al., Proteomic identification of glyceraldehyde 3-phosphate dehydrogenase as an inhibitory target of hydrogen peroxide in Arabidopsis. Plant Physiol. Biochem. 2005, 43, 828-835.

[39] Boutilier, R.G., St-Pierre, J., Surviving hypoxia without really dying. Comp. Biochem. Physiol. 2000, $126 A, 481-490$.

[40] Wu, B.S., Lee, J.K., Thompson, K.M., Walker, V.K., et al., Anoxia induces thermotolerance in the locust flight system. J. Exp. Biol. 2002, 205, 815-827.

[41] Opassiri, R., Pomthong, B., Onkoksoong, T., Akiyama, T., et al., Analysis of rice glycosyl hydrolase family 1 and expression of Os4bglu12 $\beta$-glucosidase. BMC Plant Biol. 2006, 6, art. no. 33 . 
[42] Bae, M.S., Cho, E.J., Choi, E.Y., Park, O.K., Analysis of the Arabidopsis nuclear proteome and its response to cold stress. Plant J., 2003, 36, 652-663.

[43] Guy, C.L. Freezing tolerance of plants: Current understanding and selected emerging concepts. Can. J. Bot. 2003, 81, 1216-1223.

[44] Nguyen, H.T., Weng, J., Joshi, C.P., A wheat (Triticum aestivum) cDNA clone encoding a plastid-localized heat-shock protein. Plant Physiol. 1993, 103, 675-676.

[45] Brandt, J., Thordal-Christensen, H., Vad, K., Gregersen, P.L. and Collinge, D.B., A pathogeninduced gene of barley encodes a protein showing high similarity to a protein kinase regulator. Plant J. 1992, 2, 815-820.

[46] Gregersen, P.L., Thordal-Christensen, H., Forster, H., Collinge, D.B., Differential gene transcript accumulation in barley leaf epidermis and mesophyll in response to attack by Blumeria graminis f.sp. hordei (syn. Erysiphe graminis f.sp. hordei). Physiol. Mol. Plant Pathol. 1997, 51, 85-97.

[47] Faris, J.D., Li, W.L., Liu, D.J., Chen, P.D., Gill, B.S., Candidate gene analysis of quantitative disease resistance in wheat. Theor. Appl. Genet. 1999, 98, 219-225.

[48] Christensen, A.B., Gregersen, P.L., Olsen, C.E., Collinge, D.B., A flavonoid 7-Omethyltransferase is expressed in barely leaves in response to pathogen attack. Plant Mol. Biol. $1998,36,219-227$.

[49] Sancho, A.I., Gillabert, M., Tapp, H., Shewry, P.R., et al., Effect of environmental stress during grain filling on the soluble proteome of wheat (Triticum aestivum) dough liquor. $J$. Agric. Food Chem. 2008, 56, 5386-5393.

[50] Rasmussen, S.K., Klausen, J., Hejgaard, J., Svensson, B., Svendsen, I., Primary structure of the plant serpin BSZ7 having the capacity of chymotrypsin inhibition. Biochim. Biophys. Acta $1996,1297,127-130$.

[51] Oøstergaard, H., Rasmussen, S.K., Roberts, T.H., Hejgaard, J., Inhibitory serpins from wheat grain with reactive centers resembling glutamine-rich repeats of prolamin storage proteins. 
Cloning and characterization of five major molecular forms. J. Biol. Chem. 2000, 275, 3327233279.

[52] Roberts, T.H., Marttila, S., Rasmussen, S.K., Hejgaard, J., Differential gene expression for suicide-substrate serine proteinase inhibitors (serpins) in vegetative and grain tissues of barley. J. Exp. Bot. 2003, 54, 2251-2263.

[53] Salt, L.J., Robertson, J.A., Jenkins, J.A., Mulholland, F., Mills, E.N.C., The identification of foam-forming soluble proteins from wheat (Triticum aestivum) dough. Proteomics 2005, 5, 1612-1623.

[54] Roberts, T.H., Hejgaard, J., Serpins in plants and green algae. Funct. Integr. Genom. 2008, 1, 1-27.

[55] Østergaard, O., Finnie, C., Laugesen, S., Roepstorff, P., Svensson, B., Proteome analysis of barley seeds: Identification of major proteins from two-dimensional gels (pI 4-7). Proteomics. $2004,4,2437-2447$

[56] Šotkovský, P., Hubálek, M., Hernychová, L., Novák, P., et al., Proteomic analysis of wheat proteins recognized by IgE antibodies of allergic patients. Proteomics 2008, 8, 1677-1691.

[57] Veena, Reddy V.S., Sopory S.K., Glyoxalase I from Brassica juncea: molecular cloning, regulation and its over-expression confer tolerance in transgenic tobacco under stress. Plant J. $1999,17,385-395$.

[58] Singla-Pareek, S.L., Reddy, M.K., Sopory, S.K., Genetic engineering of the glyoxalase pathway in tobacco leads to enhanced salinity tolerance. PNAS 2003, 100, 14672-14677.

[59] Yadav, S.K., Singla-Pareek, S.L., Reddy, M.K., Sopory, S.K., Transgenic tobacco plants overexpressing glyoxalase enzymes resist an increase in methylglyoxal and maintain higher reduced glutathione levels under salinity stress. FEBS Letters 2005, 579, 6265-6271.

[60] Tunnacliffe, A., Wise, M.J. The continuing conundrum of the LEA proteins. Naturwissenschaften 2007, 94, 791-812. 
[61] Bystrova, M.F., Budanova, E.N., Novoselov, V.I., Fesenko, E.E., Analysis of the oligomeric state of rat 1-Cys peroxiredoxin. Biophysics 2007, 52, 277-281.

[62] Majoul, T., Bancel, E., Triboï, E., Ben Hamida, J., Branlard, G., Proteomic analysis of the effect of heat stress on hexaploid wheat grain: Characterization of heat-responsive proteins from total endosperm. Proteomics 2003, 3, 175-183.

[63] Bustos, D.M., Bustamante C.A., Iglesias A.A., Involvement of non-phosphorylating glyceraldehyde-3 phosphate dehydrogenase in response to oxidative stress. J. Plant Physiol. 2008, 165, 456-461. 
Tab.1 Proteins responsive to heat shock identified by PMF and MS-MS analysis. The following criteria were used: MASCOT score ( $<<0.05$ ), minimal coverage 13\%, at least 6 independent peptides should match with a mass tolerance of $50 \mathrm{ppm}$ and 1 miss cleavage site. The database search was applied in NCBInr and TIGR wheat. For all the identifications three peptide fragmentations were done (MS-MS) and used in combination in the database search. The ANOVA value for each spot, the fold change of the normalized volumes between the spots in the control and heat stressed maps, the proteins names, accession numbers, the MASCOT scores, the protein coverage and the theoretical molecular weight of the proteins identified are reported.

\begin{tabular}{|c|c|c|c|c|c|c|c|}
\hline Spot & Anova & Fold Change & Protein & Accession & Species & Score/coverage\% & Theor Mw (kDa) \\
\hline \multicolumn{8}{|c|}{ Up-regulated proteins } \\
\hline 14 & $1.58 \mathrm{E}-05$ & 1.7 & 1-Cys peroxiredoxin PER 1 & gi/1710077 & T. durum & $87 / 35$ & 24.1 \\
\hline 42 & 0.004 & 1.2 & Isoflavone reductase homolog & TC235506 & & $148 / 30$ & 42.8 \\
\hline 70 & $3.58 \mathrm{E}-05$ & 1.6 & HSP70 & gi/2827002 & T. aestivum & $83 / 21$ & 71.4 \\
\hline 89 & 0.001 & 2.2 & Serpin & gi/5734506 & T. aestivum & $96 / 21$ & 43.3 \\
\hline 94 & 4.61E-04 & 2 & Serpin & gi/5734506 & T. aestivum & $109 / 33$ & 43.3 \\
\hline 222 & $2.45 \mathrm{E}-04$ & 1.4 & Tritin & gi/147744620 & T. aestivum & $111 / 38$ & 29.5 \\
\hline 232 & 0.002 & 1.9 & Globulin-like protein & TC246874 & & $356 / 45$ & 71.1 \\
\hline
\end{tabular}




\section{Page 25 of 32}

PROTEOMICS

\begin{tabular}{|c|c|c|c|c|c|c|c|}
\hline 336 & 0.015 & 1.3 & Globulin-like protein $57 \%$ & TC246703 & & $133 / 22$ & 68.2 \\
\hline 350 & 0.002 & 1.4 & Globulin-like protein & TC246874 & & $76 / 18$ & 71.1 \\
\hline 362 & 0.008 & 1.5 & $\begin{array}{l}\text { Endogenous } \alpha \text { amylase } \\
\text { inhibitor (WASI) }\end{array}$ & gi/123975 & H. vulgare & $232 / 85$ & 14.7 \\
\hline 390 & 0.033 & 1.2 & Globulin-like protein & TC246703 & & $257 / 27$ & 68.2 \\
\hline 395 & 0.033 & 1.3 & Serpin & gi/5734506 & T. aestivum & $74 / 29$ & 43.3 \\
\hline 413 & 0.008 & 1.4 & Globulin-like protein & TC246703 & & $133 / 19$ & 68.2 \\
\hline 426 & 0.014 & 1.2 & HSP70 & gi/476003 & H. vulgare & $87 / 30$ & 71.4 \\
\hline 427 & 0.002 & 1.2 & GAPDH cytosolic & gi/32478662 & & $103 / 53$ & 18.2 \\
\hline 436 & 0.023 & 1.5 & $\begin{array}{l}\text { Glucose and ribitol } \\
\text { dehydrogenase }\end{array}$ & TC233140 & & $113 / 17$ & 31.6 \\
\hline 444 & 0.007 & 1.3 & GAPDH & gi/148508784 & T. aestivum & $125 / 42$ & 36.6 \\
\hline 445 & 0.027 & 1.5 & $\begin{array}{c}\text { Flavonoid 7-O- } \\
\text { Methyltransferase-like (52\%) }\end{array}$ & TC252404 & & $141 / 26$ & 49.7 \\
\hline 447 & 0.026 & 1.3 & $\begin{array}{l}\text { Rubisco large subunit binding } \\
\text { protein }\end{array}$ & gi/2493650 & Secale & $141 / 38$ & 53.7 \\
\hline 453 & 0.014 & 1.2 & Globulin-like protein & TC246874 & T. aestivum & $383 / 47$ & 71.1 \\
\hline 456 & 0.049 & 1.2 & Serpin & TC236181 & & $87 / 34$ & 34.8 \\
\hline 460 & 0.01 & 1.2 & GAPDH cytosolic & gi/32478662 & T. aestivum & $103 / 53$ & 18.2 \\
\hline 468 & 0.047 & 1.4 & Embryo globulin & TC234134 & & $94 / 16$ & 76.5 \\
\hline 470 & 0.022 & 1.3 & $\begin{array}{l}\text { Glucose and ribitol } \\
\text { dehydrogenase }\end{array}$ & gi/7431022 & H. vulgare & $89 / 28$ & 31.6 \\
\hline
\end{tabular}

Wiley - VCH 


\begin{tabular}{|c|c|c|c|c|c|c|c|}
\hline 483 & 0.032 & 1.3 & $\begin{array}{l}\text { Late embryogenesis abundant } \\
\text { (LEA) }\end{array}$ & TC268629 & & $97 / 32$ & 30.5 \\
\hline 484 & 0.003 & 1.3 & $\begin{array}{l}\text { Late embryogenesis abundant } \\
\text { (LEA) }\end{array}$ & TC268629 & & $126 / 34$ & 30.5 \\
\hline 497 & 0.004 & 1.6 & HSP26 & gi/147225072 & T. aestivum & $110 / 45$ & 26.6 \\
\hline 502 & 0.006 & 1.2 & $\begin{array}{c}\text { Glucose and ribitol } \\
\text { dehydrogenase homologue }\end{array}$ & gi/7431022 & H. vulgare & $95 / 31$ & 31.6 \\
\hline 503 & 0.005 & 1.2 & GAPDH & gi/148508784 & T. aestivum & $123 / 61$ & 36.6 \\
\hline 505 & 0.01 & 1.4 & Embryo-specific protein & TC235043 & & $98 / 14$ & 37.6 \\
\hline 508 & 0.012 & 1.4 & Glyoxalase I & TC264636 & & $91 / 36$ & 44 \\
\hline 509 & 0.006 & 1.7 & Globulin-like protein & TC246874 & & $290 / 50$ & 71.1 \\
\hline 511 & 0.009 & 1.3 & Globulin-like protein & TC246703 & & $112 / 26$ & 68.2 \\
\hline 513 & 0.033 & 1.3 & $\begin{array}{l}\text { Hypothetical protein Oryza } \\
\text { with Enolase Domain }\end{array}$ & gi/115451911 & O.sativa & $69 / 22$ & 51.1 \\
\hline 514 & 0.046 & 1.2 & GAPDH cytosolic & $\begin{array}{l}\mathrm{gi} / 120680 \\
\text { TC264316 }\end{array}$ & & $119 / 28$ & 36.6 \\
\hline \multicolumn{8}{|c|}{ Down regulated proteins } \\
\hline 109 & 0.018 & -1.3 & Phosphoglycerate Kinase & gi/129916 & T. aestivum & $176 / 43$ & 42.1 \\
\hline 110 & 0.016 & -1.6 & ATP Synthase $\beta$ subunit & $\begin{array}{l}\text { gi/525291 and } \\
\text { TC264886 }\end{array}$ & T. aestivum & $123 / 21$ & 77.5 \\
\hline 110 & 0.016 & -1.6 & Globulin-like protein & TC246874 & & $104 / 23$ & 71.1 \\
\hline 140 & $8.82 \mathrm{E}-04$ & -1.6 & Tritin & gi/391929 & T. aestivum & $112 / 24$ & 29.5 \\
\hline
\end{tabular}




\section{Page 27 of 32}

PROTEOMICS

\begin{tabular}{|c|c|c|c|c|c|c|c|}
\hline 158 & 0.002 & -1.4 & ATP Syntase $\beta$ subunit & gi/525291 & T. aestivum & $81 / 13$ & 59.3 \\
\hline 173 & 0.007 & -1.3 & Glycosyl hydrolase 85 & $\mathrm{gi} / 30695320$ & A. thailiana & $85 / 29$ & 40.7 \\
\hline 239 & 0.022 & -1.2 & $\begin{array}{l}\text { Homologue to Embryo } \\
\text { globulin }\end{array}$ & TC234045 & & $163 / 41$ & 77.3 \\
\hline 245 & 0.008 & -1.3 & $\begin{array}{l}\text { Single stranded nucleic acid } \\
\text { binding protein }\end{array}$ & $\begin{array}{l}\text { gi/ } 974605, \\
\text { TC249148 }\end{array}$ & & $100 / 19$ & 19.3 \\
\hline 299 & 0.003 & -1.2 & $\begin{array}{c}\text { Fructose-6-P } 1 \\
\text { phosphotransferase }\end{array}$ & TC248170 & & $71 / 13$ & 82.3 \\
\hline 341 & 0.007 & -1.4 & 14-3-3 homologue & $\begin{array}{l}\text { gi/22607 and } \\
\text { TC233195 }\end{array}$ & H. vulgare & $172 / 47$ & 29.4 \\
\hline
\end{tabular}




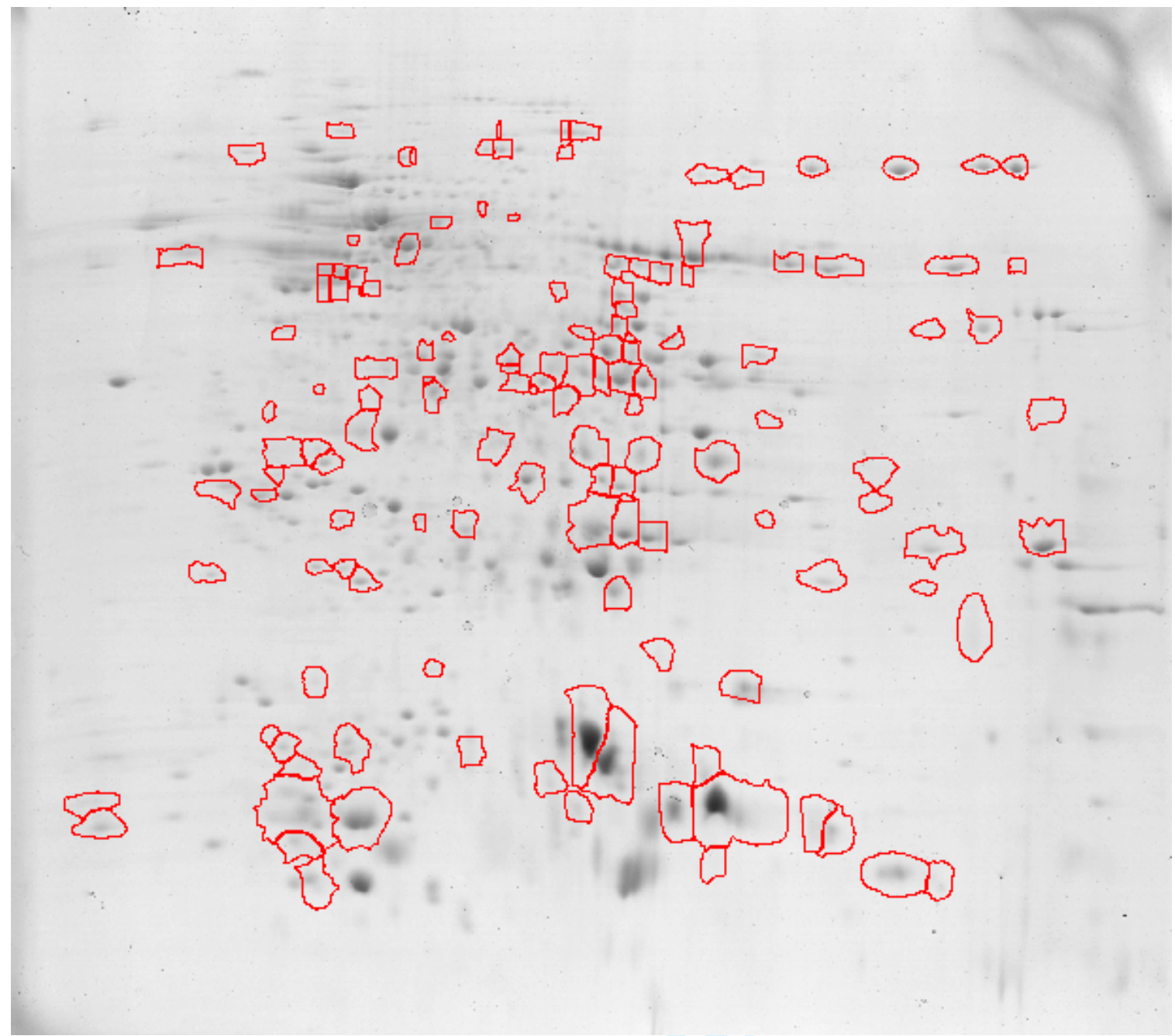

Fig. 1. 2-D PAGE map of metabolic proteins in the 3-10 $\mathrm{pH}$ range: circles indicate the differential spots 


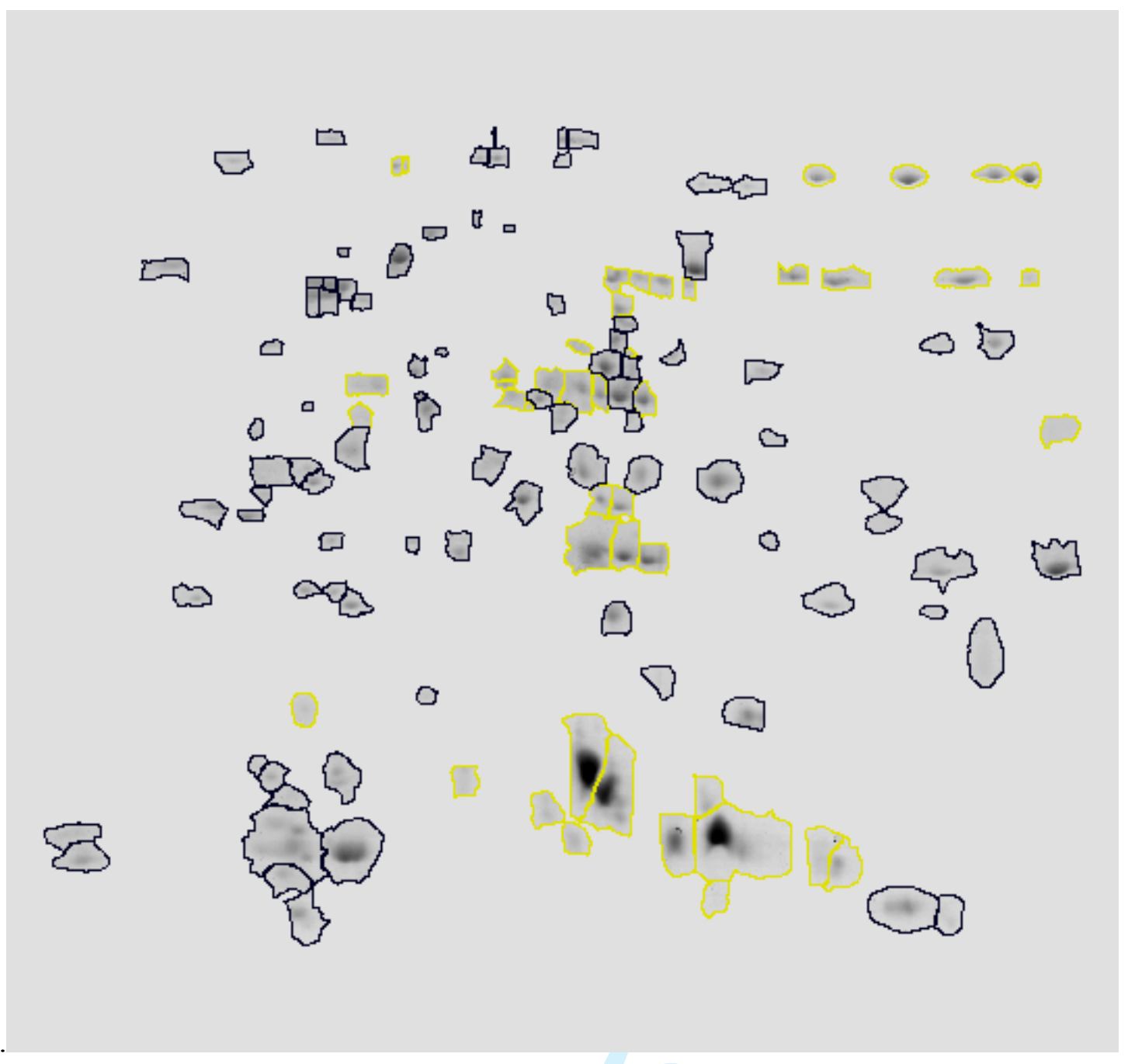

FIG 2 2D-PAGE of the metabolic proteins that are differentially regulated after the heat treatment: the yellow selection is referred to spots down-regulated, whereas the black one to up-regulated (fold change between 1.2 and 2.2). In the map all other proteins not involved in the heat response have been removed. 


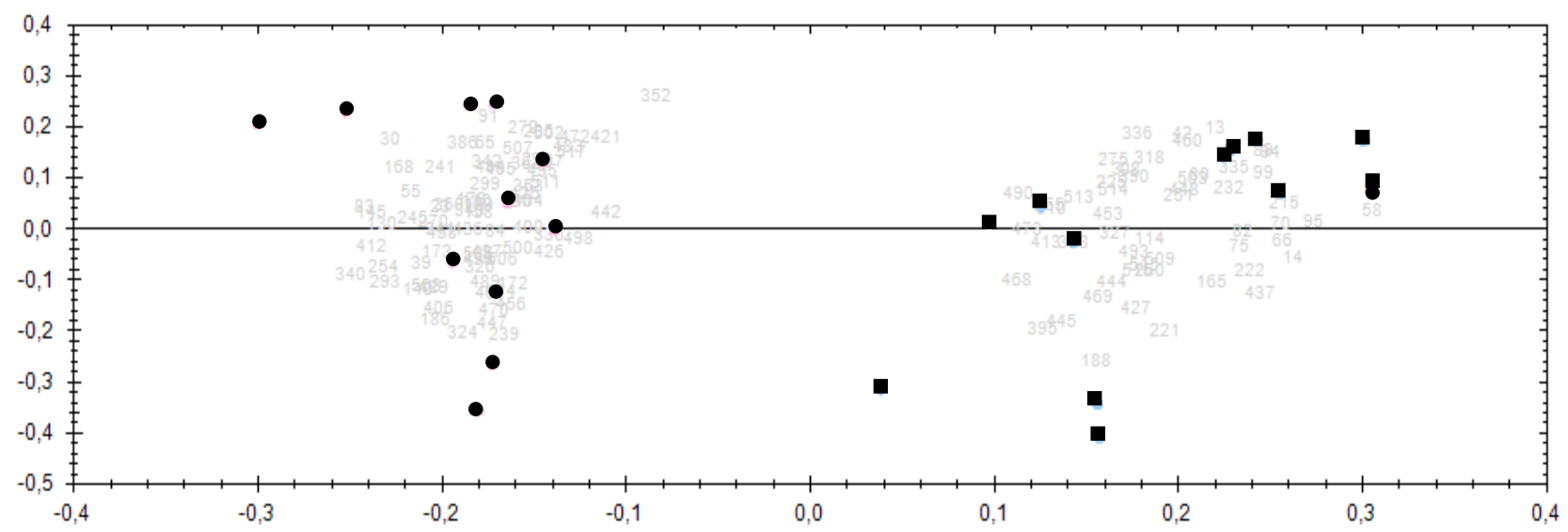

Fig. 3. PCA representation in which differential spots relative to each gel analysed are reported.

Circles: heat stressed samples; squares: control samples. Numbers represent the differentially expressed spots. 


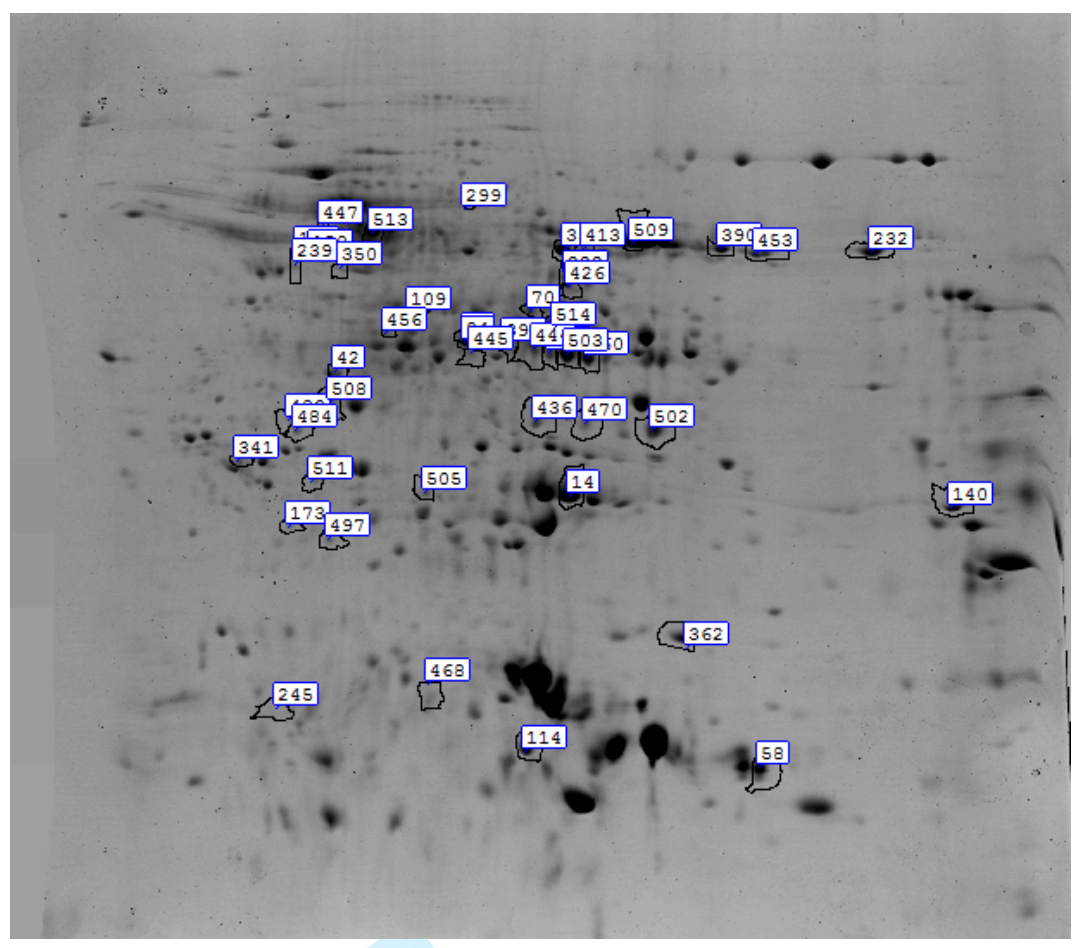

Fig. 4. 2-D PAGE map of metabolic proteins in the 3-10 $\mathrm{pH}$ range: circles indicate the identified proteins by MALDI-TOF and MALDI-TOF-TOF 